Vol. 8 No. 4 Desember 2019

E-ISSN: 2502-3101 P-ISSN: 2302-528x

http: //ojs.unud.ac.id/index.php/jmhu

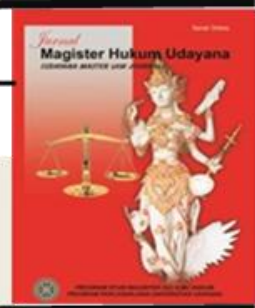

\title{
Implementasi Kebijakan Gubernur Bali Tentang Komisi Penyelenggara Perlindungan Anak Daerah dalam Perlindungan dan Pemenuhan Hak Anak
}

\section{Wayan Eka Wijaya ${ }^{1}$, Luh Nila Winarni' ${ }^{2}$, Cokorde Istri Dian Laksmi Dewi ${ }^{3}$, Ida Ayu Putu Sri Widnyani ${ }^{4}$}
1Program Studi Magister Ilmu Administrasi, Program Pascasarjana Universitas Ngurah Rai,
E-mail: iwayanekawijaya@gmail.com
2Program Studi Magister Ilmu Hukum Program Pascasarjana Universitas Ngurah Rai,
E-mail: luhnilawinarni@gmail.com
3Program Studi Magister Ilmu Hukum Program Pascasarjana Universitas Ngurah Rai, E-mail: cokdild@gmail.com
4Program Studi Magister Ilmu Administrasi, Program Pascasarjana Universitas Ngurah Rai, E-mail: dayusriwid@gmail.com

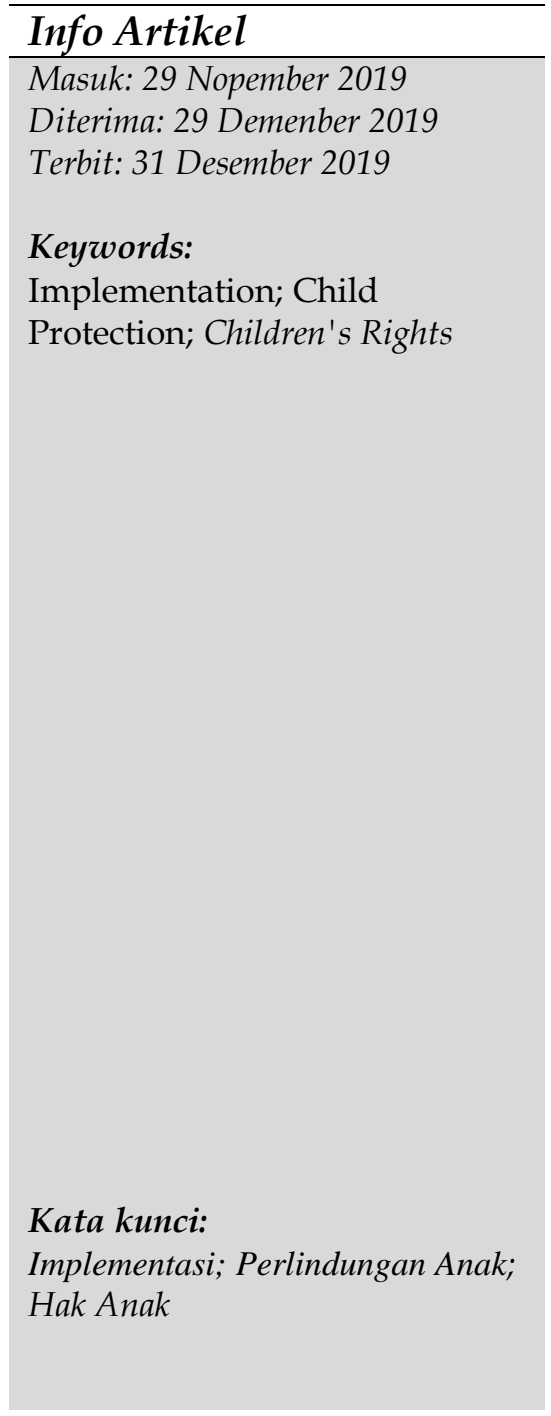

\begin{abstract}
Supervision of child protection was legitimized within Policy of the Governor of Bali Regulation No. 48 of 2015 concerning the Commission for the Management of Children of the Province of Bali. In this study, there are two issues that will be examined namely how is the implementation of the Bali the Governor of Bali Regulation No. 48 of 2015 concerning the Commission for the Management of Children of the Province of Bali and how are the efforts being made to overcome obstacles in the protection and fulfillment of children's rights in Bali? This research uses the theory of the Van Metter and Van Horn Implementation Model. The research method used is to use a qualitative approach. Data analysis in the study was carried out interactively using interactive models from Miles and Huberman. The results of the study concluded that the implementation of the Bali Governor of Bali Regulation No. 48 of 2015 concerning the Commission for the Management of Children of the Province of Bali has not been effective in fulfilling and protecting children's rights. Regional Child Protection Organizing Commission has not been able to optimally carry out its duties as a supervisor of the implementation of child protection in the Province of Bali. Efforts are being made to overcome obstacles in the protection and fulfillment of children's rights in Bali by establishing communication and coordination and making a joint commitment in the form of an MoU with several parties organizing child protection in the Province of Bali.
\end{abstract}

\footnotetext{
Abstrak

Pengawasan terhadap perlindungan anak di Provinsi Bali dilegitimasi melalui Gubernur Bali membentuk Komisi Penyelenggara Perlindungan Anak Daerah Provinsi Bali melalui Kebijakan Peraturan Gubernur Bali Nomor 48 Tahun 2015 tentang Komisi Penyelenggara Perlindungan Anak Daerah
} 


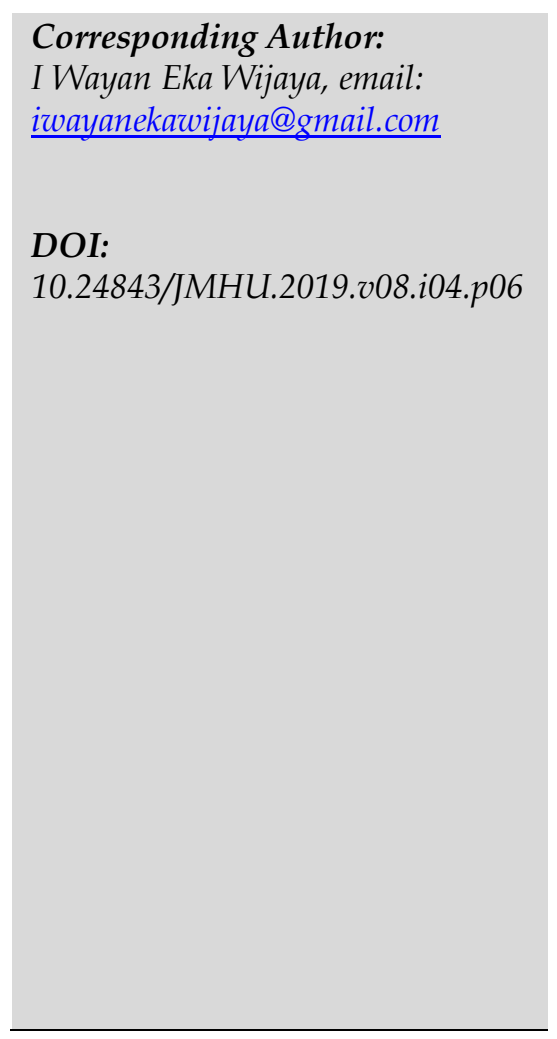

\begin{abstract}
Provinsi Bali. Dalam penelitian ini, terdapat dua permasalahan yang akan dikaji yakni bagaimanakah implementasi Peraturan Gubernur Bali Nomor 48 Tahun 2015 tentang Komisi Penyelenggara Perlindungan Anak Daerah Provinsi Bali dan bagaimanakah upaya yang dilakukan untuk mengatasi kendala dalam perlindungan dan pemenuhan hak anak di Bali? Penelitian ini menggunakan teori Model Implementasi Van Metter dan Van Horn. Metode penelitian yang digunakan adalah mempergunakan pendekatan kualitatif. Analisis data dalam penelitian dilakukan secara interaktif dengan menggunakan model interaktif dari Miles dan Huberman. Hasil penelitian menyimpulkan bahwa implementasi Peraturan Gubernur Bali Nomor 48 Tahun 2015 tentang Komisi Penyelenggara Perlindungan Anak Daerah Provinsi Bali belum efektif dalam memenuhi dan melindungi hak anak. Komisi Penyelenggara Perlindungan Anak Daerah belum bisa optimal dalam melaksanakan tugasnya sebagai pengawas pelaksanaan perlindungan anak di Provinsi Bali. upaya yang dilakukan untuk mengatasi kendala dalam perlindungan dan pemenuhan hak anak di Bali adalah dengan membangun komunikasi dan koordinasi serta membuat suatu komitmen bersama berupa MoU dengan dengan beberapa pihak yang menyelenggarakan perlindungan anak di Provinsi Bali.
\end{abstract}

\section{Pendahuluan}

Kasus-kasus yang melibatkan anak di Indonesia, termasuk pula di Bali semakin hari semakin memprihatinkan. Berbagai permasalahan yang terjadi pada anak seperti kenakalan remaja, kekerasan seksual, hingga perdagangan anak tentu memerlukan perhatian yang lebih besar. Terlebih lagi dengan perkembangan teknologi dan informasi yang menyebabkan anak lebih mudah terhubung dengan dunia luar yang membahayakan anak dan kemungkinan berinteraksi dengan predator anak. Kondisi ini direspon oleh pemerintah dengan menyelenggarakan berbagai program perlindungan anak seperti pembentukan kota layak anak di tingkat kabupaten dan kota.

Perlindungan anak menjadi hal yang penting karena anak sesungguhnya merupakan bagian dari keberlangsungan hidup manusia, suatu bangsa dan negara. Agar anak dapat bertumbuh secara optimal, maka negara wajib menyediakan dan memberikan akses yang seluas-luasnya bagi anak untuk tumbuh dan berkembang baik secara fisik, mental dan kehidupan sosial anak. Setiap anak memiliki hak untuk bertumbuh dan berkembang, memiliki kebebasan, terjamin kelangsungan hidupnya, dapat berpartisipasi serta terhindar dari tindak kekerasan dan diskriminasi. ${ }^{1}$ Pemenuhan hak-hak anak yang diselenggarakan oleh negara bertujuan untuk menjamin kesejahteraan untuk semua anak tanpa adanya diskriminasi.

Pada tahun 2002, Indonesia telah memiliki Undang-Undang Nomor 23 Tahun 2002 tentang Perlindungan Anak. Dalam perjalanannya, perlindungan anak masih kurang

\footnotetext{
1 Yastami, N. K. A., Pascarani, N. N. D., \& Purnamaningsih, P. E. (2017). Implementasi Peraturan Daerah Provinsi Bali Nomor 6 Tahun 2014 Tentang Perlindungan Anak (Studi Kasus: Tukang Suwun Anak di Pasar Badung). Citizen Charter, 1(1), p. 1.
} 
efektif. Hal ini dapat dilihat dari peningkatan jumlah kekerasan terhadap anak baik dari segi kualitas maupun kuantitas. Sebagai upaya untuk mengatasi hal tersebut, maka pemerintah mengundangkan Undang-Undang Nomor 35 Tahun 2014 tentang Perubahan Atas Undang-Undang Nomor 23 Tahun 2002 tentang Perlindungan Anak. Undang-undang perubahan menitikberatkan pada pemberatan sanksi apabila kejahatan dilakukan terhadap anak. Aturan tersebut juga memberikan langkahlangkah konkrit untuk memulihkan kondisi fisik dan psikis dari anak baik anak yang berkonflik dengan hukum, anak korban maupun anak saksi.

Sebagai wujud tanggungjawab terhadap Perlindungan Anak, Pemerintah Provinsi Bali telah menetapkan Peraturan Daerah Nomor 6 Tahun 2014 tentang Perlindungan Anak. Untuk melaksanakan pengawasan terhadap perlindungan anak maka dibentuk Komisi Penyelenggara Perlindungan Anak Daerah Provinsi Bali berdasarkan Peraturan Daerah Provinsi Bali Nomor 6 tahun 2014 dan Peraturan Gubernur Bali Nomor 48 Tahun 2015 dikukuhkan pada tanggal 6 Oktober 2016. Permasalahan atau kasus terkait anak yang banyak terjadi di Provinsi Bali pada Januari-Desember 2017 adalah Anak yang berhadapan dengan hukum, seperti korban kekerasan seksual, anak pelaku kriminal, isu penculikan anak, prasarana dan sarana publik yang kurang layak untuk anak seperti akses ke sekolah, gedung sekolah yang nyaris longsor, serta kasus keracunan makanan pada anak.

Kasus kekerasan terhadap anak di Provinsi Bali terus terjadi setiap tahun dan pada tahun 2018 mengalami peningkatan dari tahun sebelumnya. Jumlah penduduk Bali yang mayoritas atau setengahnya anak mengakibatkan Bali menjadi penyangga persoalan sosial yang tidak sederhana dengan beragamnya kasus kekerasan terhadap anak. $^{2}$

Dinas Pemberdayaan Perempuan dan Perlindungan Anak Provinsi Bali tahun 2015 sampai 2018 telah mencatat terjadinya tindak kekerasan terhadap anak di Provinsi Bali sebagaimana tersaji dalam tabel berikut :

Tabel 1.1 Kasus Kekerasan terhadap anak di Provinsi Bali tahun 2015 - 2018

\begin{tabular}{lllll}
\hline Jenis Kelamin & \multicolumn{4}{c}{ Tahun } \\
\cline { 2 - 5 } & 2015 & 2016 & 2017 & 2018 \\
\hline Laki & 57 & 44 & 113 & 112 \\
\hline Perempuan & 140 & 124 & 110 & 145 \\
\hline Jumlah & 197 & 168 & 223 & 257 \\
\hline
\end{tabular}

sumber : Dinas Pemberdayaan Perempuan dan Perlindungan Anak Provinsi Bali

Kasus - kasus yang ditangani oleh Komisi Penyelenggara Perlindungan Anak Daerah tahun 2017 - 2018 tersaji dalam tabel dibawah ini :

Tabel 1.2 Kasus yang ditangani oleh Komisi Penyelenggara Perlindungan Anak Daerah tahun 2017 - 2018

\begin{tabular}{ccc}
\hline No & Jenis kasus & Kabupaten/Kota \\
\hline 1 & Penculikan anak & Karangasem \\
\hline
\end{tabular}

\footnotetext{
2 Andreas, P., Wiasti, N.M. \& Suarsana, I.N. (2017). Strategi Penanganan Anak Korban Kekerasan Seksual oleh Lembaga Perlindungan Anak Provinsi Bali. Jurnal Humanis, Fakultas Ilmu Budaya Unud, 18(1), 269-275, p. 270.
} 


\begin{tabular}{lll}
\hline & & Gianyar \\
& & Buleleng \\
\hline 2 & Pelecehan seksual & Buleleng \\
Karangasem \\
& & Tabanan \\
\hline 3 & Keracunan makanan & Karangasem \\
& & Buleleng \\
& & Badung \\
\hline 4 & Bencana alam & Bangli \\
\hline 5 & Akses mendapatkan pendidikan & Buleleng \\
& & Badung \\
& & Gianyar \\
\hline 6 & Kecelakaan di fasilitas publik & Denpasar \\
\hline 7 & Kekerasan dalam Rumah Tangga (KDRT) & Badung \\
& & Gianyar \\
\hline 8 & Pornografi dan pornoaksi & Gianyar \\
& & Buleleng \\
\hline 9 & Bunuh diri pelajar & Denpasar \\
\hline 10 & Pembunuhan anak oleh ibu kandung & Gianyar \\
\hline 11 & Pembuangan janin & Jembrana \\
\hline 12 & Bullying & Badung \\
& & Gianyar \\
& & Denpasar \\
\hline
\end{tabular}

sumber : Komisi Penyelenggara Perlindungan Anak Daerah Provinsi Bali

Komisi Penyelenggara Perlindungan Anak Daerah Provinsi Bali beranggotakan 5 orang komisioner mempunyai Program Kerja sebagai wujud eksistensinya di Provinsi Bali. Secara umum program yang dilaksanakan oleh Komisi Penyelenggara Perlindungan Anak Daerah ini dibedakan menjadi 2 jenis program yakni program prioritas, yang merupakan program untuk menguatkan keberadaan Komisi Penyelenggara Perlindungan Anak Daerah dan program rintisan yang merupakan program untuk mendukung kerja-kerja sesuai dengan tugas pokok dan fungsi Komisi Penyelenggara Perlindungan Anak Daerah. Program prioritas antara lain promotif yang meliputi kegiatan sosialisasi dan preventif yang meliputi kegiatan koordinasi, assesment, monitoring dan advokasi. Sedangkan program rintisan meliputi : pengembangan jejaring, perluasan koordinasi, pengawasan pengarusutamaan Hak Anak dan sosialisasi media .

Komisi Penyelenggara Perlindungan Anak Daerah Provinsi Bali dalam melaksanakan tugasnya terkendala oleh minimnya anggaran yang diberikan oleh Pemerintah Provinsi Bali. Pada tahun 2017 anggaran yang dialokasikan untuk KPPAD adalah sebesar Rp. 585.000.000,-. Namun pada tahun 2018 anggaran yang diterima menjadi Rp. 396.183.500,- (67,7 \%). Anggaran yang minim menyebabkan masih banyaknya kegiatan yang penting seperti sosialisasi Konvensi Hak Anak kepada Desa dan Kabupaten/Kota tidak bisa dilaksanakan secara optimal. Peraturan Daerah Nomor 6 Tahun 2014 tentang Perlindungan Anak dan keberadaan Komisi Penyelenggara Perlindungan Anak Daerah Provinsi Bali belum dikenal secara luas oleh masyarakat. Sehingga dibutuhkan suatu terobosan yang tepat sehingga dalam era kekinian ini 
masyarakat terutama masyarakat desa harus diperlakukan bukan hanya sebagai obyek tetapi harus juga menjadi subyek. Masyarakat desa harus diberdayakan agar mempunyai inisiatif agar aktif untuk mengetahui apa itu hak-hak anak sehingga diharapkan nantinya tidak ada lagi kasus kekerasan terhadap anak.

Berdasarkan beberapa masalah yang dihadapi oleh Komisi Penyelenggara Perlindungan Anak Daerah Provinsi Bali, sesuai dengan pengamatan peneliti di lapangan, maka peneliti tertarik untuk melakukan penelitian dengan mempergunakan pendekatan ilmu administrasi khususnya dari pendekatan implementasi kebijakan publik. Bagaimana implementasi Kebijakan Peraturan Gubernur Bali Nomor 48 Tahun 2015 tentang Komisi Penyelenggara Perlindungan Anak Daerah Provinsi Bali dalam meningkatkan perlindungan terhadap anak, kendala apa saja yang dihadapi oleh Komisi Penyelenggara Perlindungan Anak Daerah Provinsi Bali dalam memberikan perlindungan terhadap anak dan bagaimana solusi dalam mengatasi kendala tersebut, dan bagaimana strategi KPPAD dalam menjalin kerjasama dengan stakeholder terkait dengan perlindungan dan pemenuhan hak anak?

Tujuan penelitian ini adalah untuk mengetahui implementasi Peraturan Gubernur Provinsi Bali Nomor 48 Tahun 2015 terkait dengan apa yang dihapai oleh Komisi Penyelenggara Perlindungan Anak Daerah Provinsi Bali dalam memberikan perlindungan terhadap anak dan bagaimana solusi dalam mengatasi kendala tersebut, dan bagaimana strategi KPPAD dalam menjalin kerjasama dengan stakeholder untuk perlindungan dan pemenuhan hak anak.

\section{Metode Penelitian}

Penelitian ini dilakukan dengan mempergunakan pendekatan kualitatif. Metode kualitatif dilandaskan pada filsafat enterpretif/ postpositivisme yang digunakan untuk meneliti objek penelitian secara alamiah. Peneliti menjadi instrumen kunci. Teknik pengumpula data dilakukan dengan triangulasi data. Analisis data dilakukan secara infuktif dengan menekankan pada makna. Lokasi penelitian ini dilakukan di Sekretariat Komisi Penyelenggara Perlindungan Anak Daerah Provinsi Bali yang berlokasi di lingkungan Kantor Dinas Pemberdayaan Perempuan dan Perlindungan Anak Provinsi Bali. Dipilihnya lokasi ini karena di tempat ini semua kegiatan Komisi Penyelenggara Perlindungan Anak Daerah berpusat dan semua interaksi antar komisioner dan masyarakat terjadi di sekretariat ini. Keabsahan data sangat diperlukan dalam penelitian. Adapun teknik keabsahan data dalam penelitian ini, adalah dengan menggunakan triangulasi dari Creswell. ${ }^{3}$ Triangulasi dilakukan dengan memeriksa kembali kebenaran data yang diperoleh melalui studi kepustakaan, wawancara, dan observasi.

\section{Hasil dan Pembahasan}

\subsection{Implementasi Peraturan Gubernur Bali Nomor 48 Tahun 2015 tentang Komisi Penyelenggara Perlindungan Anak Daerah Provinsi Bali}

\footnotetext{
${ }^{3}$ Creswell, J.W. (2009). Research Design : Qualitative, Quantitative, and Mixed Methods Approaches,. Los Angeles: Sage, p. 156-157
} 
Abuse yang dilakukan terhadap anak biasa diterjemahkan sebagai penyiksaan, kekerasan, penganiayaan, atau perlakuan yang salah, perilaku tidak selayaknya dilakukan kepada anak sehingga anak mengalami kerugian atau kondisi bahaya, baik secara fisik, psikologis, maupun finansial. ${ }^{4}$ Kristina Vlahovicova, G. J. MelendezTorres, Patty Leijten, Wendy Knerr dan Frances Gardner mengatakan "Child physical abuse is an issue of global concern. Conservative estimates set global prevalence of this type of maltreatment at $25 \%$, its consequences and cost to society escalating with increasing frequency and severity of episodes" 5 (terjemahan bebas: Pelecehan fisik anak adalah masalah yang menjadi perhatian global. Perkiraan konservatif menetapkan prevalensi global dari jenis penganiayaan ini sebesar $25 \%$, konsekuensi dan biaya bagi masyarakat meningkat dengan meningkatnya frekuensi dan tingkat keparahan episode).

Keterlibatan orang tua dalam pengasuhan sangat penting untuk melindungi dan memenuhi hak-hak anak, meskipun bukan satu-satunya faktor penentu. Mengenai hal tersebut, Ronald J. Prinz "Parenting-focused intervention is not the only piece needed in a prevention strategy, but it is a critical piece nonetheless. Another contextual consideration, often overlooked, is the collective modeling and contagion effect of parenting across the entire community, for better or worse." 6 (terjemahan bebas: Intervensi yang berfokus pada pengasuhan bukan satu-satunya bagian yang diperlukan dalam strategi pencegahan, tetapi tetap merupakan bagian yang kritis. Pertimbangan kontekstual lainnya, sering diabaikan, adalah pemodelan kolektif dan efek penularan dari pengasuhan di seluruh komunitas, baik atau buruk). Untuk memberikan perlindungan dan pemenuhan hak anak secara optimal maka Pemerintah Daerah Provinsi Bali membentuk Komisi Penyelenggara Perlindungan Anak Daerah.

Komisi Penyelenggara Perlindungan Anak Daerah diatur dalam pasal 24 pada Peraturan Daerah Nomor 6 Tahun 2014 tentang Perlindungan Anak. Komisi Penyelenggara Perlindungan Anak Daerah dibentuk oleh Gubernur dimana keanggotaan Komisi Penyelenggara Perlindungan Anak Daerah diangkat dan diberhentikan oleh Gubernur setelah mendapat persetujuan DPRD Provinsi. Komisi Penyelenggara Perlindungan Anak Daerah menyampaikan laporan setiap tahun kepada Gubernur. Untuk memperkuat eksistensi Komisi Penyelenggara Perlindungan Anak Daerah maka diterbitkan Peraturan Gubernur Bali Nomer 48 Tahun 2015 tentang Komisi Penyelenggara Perlindungan Anak Daerah.

Sebagai sebuah komisi, maka Komisi Penyelenggaraan Perlindungan Anak Daerah Anak merupakan lembaga yang bersifat independen. Terbentuknya lembaga-lembaga dan komisi-komisi, ataupun korporasi-korporasi yang bersifat independent merupakan suatu gejala yang mendunia. Fenomena ini tidak hanya di Indonesia, namun juga di negara lain seperti di Inggris dan Amerika Serikat. Komisi-komisi itu ada yang berada dalam ranah eksekutif, tetapi adapula yang bersifat independent di luar wilayah kekuasaan eksekutif, legislatif ataupun yudikatif.7

\footnotetext{
4 Probosiwi, R., \& Bahransyaf, D. (2015). Pedofilia dan kekerasan seksual: Masalah dan perlindungan terhadap anak. Sosio Informa, 1(1)., 29-40, p. 31.

5 Vlahovicova, K., Melendez-Torres, G. J., Leijten, P., Knerr, W., \& Gardner, F. (2017). Parenting programs for the prevention of child physical abuse recurrence: a systematic review and meta-analysis. Clinical child and family psychology review, 20(3), 351-365, p. 351.

6 Prinz, R. J. (2016). Parenting and family support within a broad child abuse prevention strategy: Child maltreatment prevention can benefit from public health strategies. Child abuse E neglect, 51, 400.

7 Fauzan, M. (2010). Eksistensi Komisi Negara Dalam Sistem Ketatanegaraan Republik Indonesia (Studi Terhadap Komisi Perlindungan Anak Indonesia). Jurnal Media Hukum, 17(2), 298-312, p. 299.
} 
Ditinjau dari sisi penyelenggaraan pemerintahan, Menteri Dalam Negeri melimpahkan kewenangan pembinaan dan pengawasan kepada Gubernur dalam rangka penyelenggaraan Pemerintahan Daerah yang efektif dan efisien Pelaksanaan pengawasan terhadap penyelenggaraan Pemerintahan Daerah, termasuk dalam kaitannya dengan upaya pemenuhan dan perlindungan hak anak dilakukan berdasarkan amanat Peraturan Pemerintah Nomor 20 tahun 2001 tentang Pembinaan dan Pengawasan atas penyelenggaraan Pemerintahan Daerah. Hal ini dimaksudkan untuk memberikan penguatan peran Gubernur selaku Wakil Pemerintah dalam penyelenggaraan Otonomi Daerah. ${ }^{8}$

Dalam implementasi Peraturan Gubernur ini ternyata banyak sekali kendala yang dihadapi oleh Komisi Penyelenggara Perlindungan Anak Daerah dalam menunjukkan eksistensinya sebagai lembaga independen dibawah Gubernur yang mempunyai tugas untuk melakukan pengawasan terhadap pelaksanaan perlindungan anak di Provinsi Bali.

Kendala yang terjadi antara lain belum adanya sekretariat tetap, belum maksimalnya anggaran yang besarannya masih tergantung kebijakan dari Dinas Pemberdayaan Perempuan dan Perlindungan Anak Provinsi Bali, Sumber Daya Manusia (staf administrasi dan sopir) yang terbatas, ketiadaan kendaraan operasional yang representatif, masih adanya mispersepsi dari beberapa pejabat Dinas Pemberdayaan Perempuan dan Perlindungan Anak Provinsi Bali yang menganggap Komisi Penyelenggara Perlindungan Anak Daerah merupakan bawahan Dinas Pemberdayaan Perempuan dan Perlindungan Anak Provinsi Bali karena anggaran masih menjadi satu dengan Dinas Pemberdayaan Perempuan dan Perlindungan Anak Provinsi Bali, adanya kesan Komisi Penyelenggara Perlindungan Anak Daerah harus melapor setiap kegiatan ke Dinas Pemberdayaan Perempuan dan Perlindungan Anak Provinsi Bali, sedangkan Komisi Penyelenggara Perlindungan Anak Daerah mempunyai kewajiban melaporkan hasil kegiatan ke Gubernur Bali, dan tidak adanya keleluasaan dalam berkegiatan, contohnya dalam perjalanan dalam daerah masih harus membuat surat tugas yang hanya bisa ditandatangani oleh Kepala Dinas Pemberdayaan Perempuan dan Perlindungan Anak.

\subsection{Upaya yang dilakukan untuk Mengatasi Kendala dalam Perlindungan dan Pemenuhan Hak Anak di Bali}

Gubernur dalam konteks Integrad Prefectoral System memiliki kewenangan untuk melakukan koordinasi, pengawasan, serta memfasilitasi penyelenggaraan pemerintahan daerah dalam pelaksanaan otonomi daerah secara optimal. ${ }^{9}$

Dalam implementasi kebijakan Peraturan Gubernur Bali Nomer 48 Tahun 2015 tentang Komisi Penyelenggara Perlindungan Anak Daerah masih belum optimal karena masih terjadi kendala dalam operasional sehari hari Komisi Penyelenggara Perlindungan Anak Daerah sebagai lembaga Independen di bawah Gubernur sesuai amanat Peraturan Daerah Provinsi Bali Nomor 6 Tahun 2014. Selain itu nama Komisi Penyelenggara Perlindungan Anak Daerah menimbulkan kesan yang rancu dimana

\footnotetext{
${ }^{8}$ Harahap, M. S. (2018). Evaluasi Kebijakan Pemerintah Dalam Mendukung Penegakan Hukum Dan Hak Asasi Manusia. Jurnal Ilmiah Hukum Dirgantara, 3(2), 21-27, p. 26.

${ }^{9}$ Hadiwijoyo, S.S. (2011). Gubernur; Kedudukan, Peran, dan Kewenangan. Yogyakarta: Graha Ilmu, p. 129.
} 
Komisi Penyelenggara Perlindungan Anak Daerah dianggap sebagai penyelenggara perlindungan anak di daerah.

Untuk itu perlu segera dibentuk sekretariat tetap Komisi Penyelenggara Perlindungan Anak Daerah dengan sumber daya manusia dan anggaran yang optimal untuk menjalankan sebuah Komisi Independen dibawah Gubernur dan Nama Komisi Penyelenggara Perlindungan Anak Daerah perlu segera dirubah menjadi Komisi Pengawas Perlindungan Anak Daerah agar tidak menimbulkan kerancuan yang menganggap bahwa Komisi Penyelenggara Perlindungan Anak Daerah adalah penyelenggara bukan sebagai pengawas sebagaimana diamanatkan pada Peraturan Gubernur Nomor 48 Tahun 2015.

Dalam menganalisis permasalahan dalam penelitian ini, maka digunakan pendapat dari Van Meter dan Van Horn yang mengemukakan mengenai model of policy implementation process. Model ini menganggap bahwa implementasi kebijakan dipengaruhi oleh dimensi kebijakan di arahkan untuk mencapai tujuan-tujuan yang telah di tetapkan dalam keputusan- keputusan kebijakan sebelumnya. ${ }^{10}$

Berdasarkan model Implementasi Van Metter dan Van Horn, analisis implementasi dilakukan berdasarkan 6 variabel yang saling berkaitan antara lain (1) Standar dan sasaran kebijakan, (2) Sumber daya, (3) Karakteristik organisasi pelaksana, (4) Sikap para pelaksana, (5) Komunikasi antar organisasi terkait dan kegiatan-kegiatan pelaksanaan, (6) Lingkungan sosial, ekonomi, dan politik.

\section{(1) Standar dan sasaran kebijakan}

Komisi Penyelenggara Perlindungan Anak Daerah dibentuk sebagai amanat dari Peraturan Daerah Provinsi Bali Nomor 6 Tahun 2014 tentang Perlindungan Anak pasal 24. Komisi Penyelenggara Perlindungan Anak Daerah merupakan lembaga independen langsung dibawah Gubernur. Keberadaan Komisi Penyelenggara Perlindungan Anak Daerah diperkuat dengan terbitnya Peraturan Gubernur Nomor 48 Tahun 2015 tentang Komisi Penyelenggara Perlindungan Anak Daerah dimana tugas dan fungsi Komisi Penyelenggara Perlindungan Anak Daerah antara lain :

a. Melakukan tindakan pengawasan dalam menjamin perlindungan dan pemenuhan hak-hak anak di daerah;

b. Memberikan masukan kepada pemerintah daerah dalam perencanaan program;

c. Melakukan koordinasi, serta sosialisasi tentang perlindungan anak di daerah;

d. Memberikan laporan tentang adanya dugaan pelanggaran terhadap undangundang tentang perlindungan anak kepada pihak berwajib;

e. Mengumpulkan data dan informasi mengenai perlindungan anak;

f. Melakukan pemantauan, advokasi, dan evaluasi perencanaan dan pelaksanaan perlindungan anak di daerah; dan

g. Melakukan inventarisasi serta melaporkan pelaksanaan program dan penanganan kasus perlindungan anak di daerah

h. Menghimpun informasi/keterangan kepada SKPD, lembaga/institusi terkait berkenaan dengan penyelenggaraan perlindungan anak;

10 Masriani, M., \& Sujianto, S. (2017). Implementasi Kebijakan Tentang Perlindungan Anak (Studi Kasus Anak-anak Pengemis di Kecamatan Mandau). Jurnal Online Mahasiswa Fakultas Ilmu Sosial dan Ilmu Politik Universitas Riau, 4(2), 1-13, p. 6. 
i. Memfasilitasi pengaduan masyarakat untuk dikoordinasikan dengan SKPD, lembaga/institusi terkait berkenaan dengan penyelenggaraan perlindungan anak; dan

j. Mengakomodir isu-isu strategis sebagai bahan penyusunan program dan kegiatan lebih lanjut.

Komisi Penyelenggara Perlindungan Anak Daerah sejak dibentuk pada tahun 2016 sudah melaksanakan kegiatan sebagaimana diamanatkan sesuai tupoksi yang diberikan dan rutin membuat laporan kepada Gubernur setiap tahun. Komisi Penyelenggara Perlindungan Anak Daerah juga sudah terlibat aktif dalam memfasilitasi pengaduan masyarakat dan menyampaikan isu-isu strategis saat diundang rapat oleh DPRD Provinsi Bali.

\section{(2) Sumber Daya}

Komisi Penyelenggara Perlindungan Anak Daerah yang dibentuk sejak tahun 2016 terdiri dari 5 orang komisioner terdiri dari seorang Ketua merangkap anggota, seorang wakil ketua merangkap anggota, dan 3 orang anggota. Dalam operasional sehari hari dibantu oleh satu orang staf administrasi yang merupakan tenaga kontrak. Tidak ada personil PNS di sekretariat sementara Komisi Penyelenggara Perlindungan Anak Daerah di Dinas Pemberdayaan Perempuan dan Perlindungan Anak Provinsi Bali. Dana operasional Komisi Penyelenggara Perlindungan Anak Daerah berasal dari APBD Provinsi Bali melalui DPA Dinas Pemberdayaan Perempuan dan Perlindungan Anak dan dikelola oleh seorang Pejabat Pelaksana Teknis Kegiatan (PPTK). Komisi Penyelenggara Perlindungan Anak Daerah tidak memiliki kendaraan operasional dan dalam pelaksanaan kegiatan lapangan mesti meminjam ke Dinas Pemberdayaan Perempuan dan Perlindungan Anak Provinsi Bali Provinsi Bali. Dana yang selama ini diberikan ke Komisi Penyelenggara Perlindungan Anak Daerah dirasa masih sangat minim. Dan sebagai konskuensi dari dana yang masih terikat dengan Dinas Pemberdayaan Perempuan dan Perlindungan Anak Provinsi Bali, maka saat terjadi rasionalisasi berupa pemotongan anggaran pada tahun 2018, Komisi Penyelenggara Perlindungan Anak Daerah mengalami pemotongan anggaran perjalanan dinas dalam dan luar daerah yang cukup signifikan. Sehingga pada tahun 2018, Komisi Penyelenggara Perlindungan Anak Daerah tidak bisa optimal melakukan pengawasan akibat dana perjalanan dinas dalam daerah yang merupakan komponen utama kegiatan pengawasan dipotong.

\section{(3) Karakteristik Agen Pelaksana}

Komisi Penyelenggara Perlindungan Anak Daerah dibentuk untuk membantu pemerintah daerah dalam perencanaan program kegiatan perlindungan anak, melakukan berbagai sosialisasi, koordinasi, serta penyuluhan tentang perlindungan anak. Komisi tersebut juga bertugas dalam memberikan advokasi, melakukan pemantauan serta melaksanakan evaluasi terhadap perencanaan dan pelaksanaan perlindungan anak. Selanjutnya komisi melakukan pencatatan dan pelaporan terhadap pelaksanaan program yang telah direncanakan tersebut dan melakukan pula pelaporan atas penanganan kasus perlindungan anak di daerah. Dalam melaksanakan kegiatan, kelima orang komisioner Komisi Penyelenggara Perlindungan Anak Daerah sudah melaksanakan tugas dengan baik sesuai yang dilaporkan kepada Gubernur setiap tahun. Seorang komisioner yang masing-masing mempunyai tanggungjawab sesuai bidangnya idealnya didampingi oleh seorang staf yang bisa membantu dalam pengurusan laporan dan administrasi pertanggungjawaban perjalanan dinas. 


\section{(4) Komunikasi antar organisasi terkait dan kegiatan-kegiatan pelaksanaan}

Eksistensi Komisi Penyelenggara Perlindungan Anak Daerah sebagai lembaga independen dibawah Gubernur harus didukung oleh semua stakeholder, karena Komisi Penyelenggara Perlindungan Anak Daerah adalah amanat dari Peraturan Daerah Nomor 6 Tahun 2014 tentang Perlindungan anak. Komisi Penyelenggara Perlindungan Anak Daerah dalam melaksanakan pengawasan perlindungan anak menerapkan prinsip independen, non diskriminasi, kemitraan, koordinasi, integrasi, sinkronisasi, dan profesionalisme baik internal dan eksternal. Untuk meningkatkan efektifitas pengawasan penyelenggaraan perlindungan anak, Komisi Penyelenggara Perlindungan Anak Daerah melakukan kerjasama dan koordinasi dengan instansi terkait, Pemerintah Daerah, Komisi Perlindungan Anak Indonesia (KPAI), aparat penegak hukum dan pihak terkait lainnya.

Masalah miskomunikasi masih sering dihadapi oleh Komisi Penyelenggara Perlindungan Anak Daerah dalam melaksanakan tugasnya. Beberapa penyelenggara perlindungan anak daerah menganggap bahwa Komisi Penyelenggara Perlindungan Anak Daerah melakukan intervensi dalam penanganan kasus di kabupaten/kota, padahal jika memahami Peraturan Gubernur Nomor 48 Tahun 2015 tentang Komisi Penyelenggara Perlindungan Anak Daerah Pasal 24 ayat 2 disebutkan bahwa pemerintah daerah, instansi terkait, aparat penegak hukum dan pihak lainnya wajib memberikan kemudahan akses kepada Komisi Penyelenggara Perlindungan Anak Daerah untuk melakukan pengawasan penyelenggaraan perlindungan anak sesuai dengan ketentuan peraturan perundang-undangan.

Miskomunikasi juga terjadi dengan Dinas Pemberdayaan Perempuan dan Perlindungan Anak Provinsi Bali Provinsi Bali, dimana Komisi Penyelenggara Perlindungan Anak Daerah dianggap sebagai bawahan dari Dinas Pemberdayaan Perempuan dan Perlindungan Anak Provinsi Bali Provinsi Bali yang wajib menyampaikan laporan kegiatan rutin kepada Dinas Pemberdayaan Perempuan dan Perlindungan Anak Provinsi Bali Provinsi Bali karena anggaran Komisi Penyelenggara Perlindungan Anak Daerah berasal dari Dinas Pemberdayaan Perempuan dan Perlindungan Anak Provinsi Bali Provinsi Bali. Padahal sudah jelas disampaikan dalam Peraturan Daerah maupun Peraturan Gubernur bahwa Komisi Penyelenggara Perlindungan Anak Daerah merupakan Lembaga Independen berada dibawah Gubernur dan menyampaikan laporan setiap tahun kepada Gubernur.

Miskomunikasi yang masih sering terjadi tentu harus disikapi oleh masing-masing pihak dengan melihat kembali peraturan yang telah dibuat, sehingga tidak mengganggu ritme kerja Komisi Penyelenggara Perlindungan Anak Daerah sebagai lembaga independen dibawah Gubernur yang melakukan pengawasan terhadap pelaksanaan perlindungan anak di Provinsi Bali.

\section{(5) Disposisi atau sikap para pelaksana}

Kebijakan pembentukan Komisi Penyelenggara Perlindungan Anak Daerah sudah diketahui oleh semua stakeholder di Kabupaten/Kota dan Provinsi. Kegiatan sosialisasi sudah dilaksanakan pada tahun 2017 dan semua stakeholder sudah memahami keberadaan Komisi Penyelenggara Perlindungan Anak Daerah . Dukungan dari stakeholder sudah mulai terlihat walaupun masih ada beberapa yang masih menolak untuk memberikan akses pengawasan akan tetapi seiring berjalannya waktu keberadaan Komisi Penyelenggara Perlindungan Anak Daerah akan mendapat 
dukungan dari semua pihak. Komunikasi yang intens antara Komisi Penyelenggara Perlindungan Anak Daerah dan stakeholder terkait sangat diperlukan di usia Komisi Penyelenggara Perlindungan Anak Daerah yang baru 2 tahun dan masih butuh dukungan sumber daya berupa anggaran, staf, kendaraan operasional, dan sekretariat tetap dari Pemerintah Provinsi Bali.

\section{(6) Lingkungan sosial, ekonomi dan politik}

Komisi Penyelenggara Perlindungan Anak Daerah dibentuk atas inisiatif DPRD Provinsi Bali agar Provinsi Bali segera membentuk lembaga independen yang mampu melakukan pengawasan terhadap perlindungan anak di Provinsi Bali. Lembaga ini dibentuk dari proses politik karena dari pengangkatan dan pemberhentian keanggotaan Komisi Penyelenggara Perlindungan Anak Daerah dilakukan oleh Gubernur setelah mendapat persetujuan DPRD Provinsi Bali. DPRD Provinsi Bali, terutama Komisi IV yang membidangi Kesejahteraan Rakyat sangat intens mengawal keberadaan dan eksistensi Komisi Penyelenggara Perlindungan Anak Daerah . Di sini tampak bahwa Gubernur Provinsi Bali dan DPRD Provinsi Bali konsisten terhadap Peraturan Gubernur Nomor 6 Tahun 2014 tentang Perlindungan Anak dengan mendukung keberadaan Komisi Penyelenggara Perlindungan Anak Daerah . Komisi Penyelenggara Perlindungan Anak Daerah selalu diundang dalam kegiatan rapat di DPRD Provinsi Bali sebagai bentuk pengakuan terhadap eksistensi Komisi Penyelenggara Perlindungan Anak Daerah

\section{Kesimpulan}

Implementasi Kebijakan Peraturan Gubernur Bali Nomor 48 Tahun 2015 tentang Komisi Penyelenggara Perlindungan Anak Daerah dalam Perlindungan dan Pemenuhan Hak Anak di Provinsi Bali, maka dapat dirumuskan beberapa kesimpulan dimana secara umum keberadaan Komisi Penyelenggara Perlindungan Anak Daerah sudah diketahui oleh sebagian besar stakeholder dan masyarakat. Komisi Penyelenggara Perlindungan Anak Daerah belum bisa optimal dalam melaksanakan tugasnya sebagai pengawas pelaksanaan perlindungan anak di Provinsi Bali. Masih ada mispersepsi dan miskomunikasi yang terjadi karena Komisi Penyelenggara Perlindungan Anak Daerah dianggap sebagai penyelenggara perlindungan anak sesuai namanya yaitu Komisi Penyelenggara Perlindungan Anak Daerah sehingga masih ada kesan bahwa Komisi Penyelenggara Perlindungan Anak Daerah mengintervensi kegiatan perlindungan anak di Kabupaten/Kota. Miskomunikasi dan mispersepsi juga terjadi di Dinas Pemberdayaan Perempuan dan Perlindungan Anak Provinsi Bali dimana sekretariat sementara Komisi Penyelenggara Perlindungan Anak Daerah berada, dimana Komisi Penyelenggara Perlindungan Anak Daerah dianggap sebagai bawahan dari Dinas Pemberdayaan Perempuan dan Perlindungan Anak Provinsi Bali sehingga wajib melaporkan kegiatan rutin kepada Kepala Dinas karena anggaran Komisi Penyelenggara Perlindungan Anak Daerah berasal dari DPA Dinas Pemberdayaan Perempuan dan Perlindungan Anak Provinsi Bali Provinsi Bali. Padahal sudah jelas bahwa Komisi Penyelenggara Perlindungan Anak Daerah adalah lembaga independen berada dibawah Gubernur dan melaporkan kegiatan kepada Gubernur setiap tahun. Jadi Komisi Penyelenggara Perlindungan Anak Daerah belum sepenuhnya independen karena "tersandera" oleh anggaran dan sekretariat sementara yang masih berada di Dinas Pemberdayaan Perempuan dan Perlindungan Anak 
Provinsi Bali Provinsi Bali. Kendala yang dihadapi Komisi Penyelenggara Perlindungan Anak Daerah dalam melaksanakan tugas dan fungsinya antara lain : (a) ketiadaan sekretariat tetap, (b) belum maksimalnya anggaran yang besarannya masih tergantung kebijakan dari Dinas Pemberdayaan Perempuan dan Perlindungan Anak Provinsi Bali, (c) Sumber Daya Manusia (staf administrasi dan sopir) yang terbatas, (d) ketiadaan kendaraan operasional yang representatif, (e) masih adanya mispersepsi dari beberapa pejabat Dinas Pemberdayaan Perempuan dan Perlindungan Anak Provinsi Bali Provinsi Bali yang menganggap Komisi Penyelenggara Perlindungan Anak Daerah merupakan bawahan Dinas Pemberdayaan Perempuan dan Perlindungan Anak Provinsi Bali karena anggaran masih menjadi satu dengan Dinas Pemberdayaan Perempuan dan Perlindungan Anak Provinsi Bali, (f) adanya kesan Komisi Penyelenggara Perlindungan Anak Daerah harus melapor setiap kegiatan ke Dinas Pemberdayaan Perempuan dan Perlindungan Anak Provinsi Bali Provinsi Bali, sedangkan Komisi Penyelenggara Perlindungan Anak Daerah mempunyai kewajiban melaporkan hasil kegiatan ke Gubernur Bali, dan (g) tidak adanya keleluasaan dalam berkegiatan, contohnya dalam perjalanan dalam daerah masih harus membuat surat tugas yang hanya bisa ditandatangani oleh Kepala Dinas Pemberdayaan Perempuan dan Perlindungan Anak. Komisi Penyelenggara Perlindungan Anak Daerah mempunyai strategi dalam menjalin kerjasama dengan stakeholder terkait dengan perlindungan dan pemenuhan hak anak. Strategi yang dilakukan adalah dengan membangun komunikasi dan koordinasi serta membuat suatu komitmen bersama berupa MoU dengan beberapa pihak yang menyelenggarakan perlindungan anak di Provinsi Bali. Pembuatan MoU dengan stakeholder terkait ternyata menemui kendala. Kendala yang dihadapi antara lain adalah mispersepsi bahwa Komisi Penyelenggara Perlindungan Anak Daerah adalah dibawah kewenangan Dinas Pemberdayaan Perempuan dan Perlindungan Anak sehingga dalam membuat kerjasama atau MoU adalah sepengetahuan Kepala Dinas Pemberdayaan Perempuan dan Perlindungan Anak. Independensi sebuah Komisi yang berada langsung dibawah Gubernur masih dipertanyakan pada tataran implementasi di lapangan.

\section{Daftar Pustaka}

\section{$\underline{\text { Buku }}$}

Creswell, J.W. (2009). Research Design : Qualitative, Quantitative, and Mixed Methods Approaches, Los Angeles: Sage.

Hadiwijoyo, S.S. (2011). Gubernur; Kedudukan, Peran, dan Kewenangan. Yogyakarta: Graha Ilmu.

\section{Jurnal}

Andreas, P., Wiasti, N.M. \& Suarsana, I.N. (2017). Strategi Penanganan Anak Korban Kekerasan Seksual oleh Lembaga Perlindungan Anak Provinsi Bali. Jurnal Humanis, Fakultas Ilmu Budaya Unud, 18(1), 269-275.

Fauzan, M. (2010). Eksistensi Komisi Negara Dalam Sistem Ketatanegaraan Republik Indonesia (Studi Terhadap Komisi Perlindungan Anak Indonesia). Jurnal Media Hukum, 17(2), 298-312.

Harahap, M. S. (2018). Evaluasi Kebijakan Pemerintah Dalam Mendukung Penegakan Hukum Dan Hak Asasi Manusia. Jurnal Ilmiah Hukum Dirgantara, 3(2), 21-27. 
Masriani, M., \& Sujianto, S. (2017). Implementasi Kebijakan Tentang Perlindungan Anak (Studi Kasus Anak-anak Pengemis di Kecamatan Mandau). Jurnal Online Mahasiswa Fakultas Ilmu Sosial dan Ilmu Politik Universitas Riau, 4(2), 1-13.

Prinz, R. J. (2016). Parenting and family support within a broad child abuse prevention strategy: Child maltreatment prevention can benefit from public health strategies. Child abuse \& neglect, 51.

Probosiwi, R., \& Bahransyaf, D. (2015). Pedofilia dan kekerasan seksual: Masalah dan perlindungan terhadap anak. Sosio Informa, 1(1)., 29-40.

Vlahovicova, K., Melendez-Torres, G. J., Leijten, P., Knerr, W., \& Gardner, F. (2017). Parenting programs for the prevention of child physical abuse recurrence: a systematic review and meta-analysis. Clinical child and family psychology review, 20(3), 351-365.

Yastami, N. K. A., Pascarani, N. N. D., \& Purnamaningsih, P. E. (2017). Implementasi Peraturan Daerah Provinsi Bali Nomor 6 Tahun 2014 Tentang Perlindungan Anak (Studi Kasus: Tukang Suwun Anak di Pasar Badung). Citizen Charter, 1(1).

\section{Peraturan Perundang - Undangan}

Undang-undang Republik Indonesia Nomor 23 Tahun 2002 Tentang Perlindungan Anak sebagiamana diubah denganUndang-undang Republik Indonesia Nomor 35 Tahun 2014 Tentang Perubahan Undang-undang Nomor 23 Tahun 2002 tentang Perlindungan Anak.

Peraturan Daerah Provinsi Bali Nomor 6 Tahun 2014 Tentang Perlindungan Anak

Peraturan Gubernur Bali Nomor 48 Tahun 2015. Tentang Komisi Penyelenggara Perlindungan Anak Daerah 